\section{THE MANEUVER OF HOUSE HOLD HERBAL REMEDIES FOR HUMAN AILMENTS AND AGRICULTURAL PESTS}

KEY WORDS: Herbal recipe,

Human Diseases, Broad Spectrum, Antibiotics, Bio pesticide etc.

\section{Dr. V. Lakshmi*}

\section{Dr. A. Solavan}

Assistant Professor of Zoology, PG and Research Centre of Zoology, PMT College, Melaneelithanallur -627 953.*Corresponding Author

Head and Associate Professor of Zoology, PG Department of Zoology and Research Centre, PMT College, Melaneelithanallur-627 953.

A steady search has been made to bring out the secrecy of herbal recipe preparations from the manuscript of various traditional medical practitioners who have been residing in the villages of Tirunelveli district, Tamil Nadu. The principal objective of the study is to document a sum of 21 plants belonging to 18 genera and 21 species widely used for human diseases such as antidote for Insect sting, Arteriosclerosis, Gastro intestinal disorders, Skin disorders, Migraine, Giddiness, Eczema, Tonsillitis, Foot crack and also as Insect repellent and Fungicide in agricultural fields. The potentiality of the herbal medicine is evaluated by observing the patients during and after the oral and external administration of herbal recipe by the rural healers. Cultivation, conservation and proper utilization of medicinal plant species are the need of hour to secure humans and agricultural crops from the adverse effects of broad spectrum of antibiotics and chemical pesticides. Further this study opens the way for making ecofriendly safe drugs and bio pesticides for mankind and cultivable plant species respectively.

\section{INTRODUCTION}

Plants and their products have been very ambitious in treating human ailment since human settlement. The traditional knowledge of herbal medicine has been reported from all ethnic groups of humans. In the under developed countries, about 330 Crore people utilize medicinal plants regularly to get rid of their illness (Dobriyal andNarayana, 1998).

Apart from the Indian traditional medicines, the folk medicines from the herbal household remedies (Sane, 2002). The WHO also appreciated the significance of medicinal plants for publichealth care and formulated guidelines to study their potential utilization concerned with evaluation, safety and efficacy (Venkata Rao, 2006). Traditional medical practitioners mostly use drug yielding plants in a crude form but modern scientists are very successful in isolating the active principle on Indian plant species (Augusti, 2006). There has been an awareness in the developing and developed countries for the revival and comprehensive use of traditional systems of medicine in many human diseases in lieu of modern medicines. Since the drugs used in allopathy have adverse effect on human health, people deliberately opt for the herbal medicines because these are safe, easily available, cheaper and more compatible to human body constitution.

In addition to the medicinal plants, men of early period utilized various plant species that include Neem, Vitez, Adhatoda, Chrysanthemum, Tobacco etc., toward off the pests in agricultural crops and their products (Narayanasamy, 2006). Some plant species are also involved traditionally in the plant protection activities 9Saleem and Gaby, 1996). Insecticidal properties of the Chrysanthemum flowers, Neem, Indian Vitex, Adhatoda, Turmeric, Holy basil etc., are brought to light (Narayanasamy, 2006 and Pradhan et al 1962). It is therefore an innate instinct of researchers to document the existing systems of herbal medicines and botanical pesticides to save humans from the daunting effects of modern medicines and ornery expenses.

\section{Methodology}

To bring out the secrecy of preparation of herbal medicines vested on the manuscripts of rural healers, a steady survey has been made among the traditional medicine men residing in ten villages across the latitude $9^{\circ} 4^{\prime} 54^{\circ}$, East longitude $77^{\circ}$ $21^{\prime} 22^{\circ}$ located near the foot hills of the Western Ghats in Tirunelveli District, Tamil Nadu. After establishing an ideal rapport with them, we interviewed ten healers with regard to the herbal recipe for the treatment of human diseases and also plants used in making botanical pesticides. The confidential of the herbal home remedies was verified with some senior citizens, professional medical practitioners and standard texts used in Siddha and Ayurveda. The authors spent more than 10 months during the year 2016 to know the methods of treatment adopted by total doctors to heal their patients. The efficacy and safety of the herbal drugs administration were confirmed by observing the humans suffering from illness and plants infested with pests. The medicinal plant species collected during 2016 from the study area were subjected to herbarium techniques and preserved at the herbarium of PMT College,Melaneelithanallur. Similarly the formula for making various medicines that were used in the treatment of human and agricultural crops infestations were documented for further studies.

Traditional preparation of Drugs/Pesticides for various human ailments/ Agricultural crops It brings out an optimistic note for people who have been struggling with ornery expenditure to overcome some common ailments or crop diseases.

\section{Antidote}

Stinging on the subcutaneous tissues of man by wasps, bees, centipedes etc. causes unbearable pain, this panic situation can be ratified by frequent applications of cell sap (5 times /day) of onion bulb over the sting hole. This drug offers better relief to the patient and favours the retrieval of the sting.

\section{Black Patch}

It seems to be a potential preparation consists of tomato fruit juice $(50 \mathrm{ml})$, Lemon juice (5ml), Cow's curd $(5 \mathrm{ml})$ and Honey (5ml) which is applied externally on the black patches of man for 30 minutes once a day for a week and wiped out in bathing. This drug also acts as a natural skin care cream.

\section{Foot Crack}

Consumption of the traditional medicine twice a day for 5 days provides a permanent cure for foot cracks in humans. The composition of the drug is the leaves of Arjunamyrobalan (1 lg) ground in Cow's milk (180ml).

\section{Arteriosclerosis}

This is a novel drug made up of the juice of the juice rhizome of ginger, the bulb of garlic, apple vinegar and the juice of lemon fruit (each $200 \mathrm{ml}$ ), this mixture is boiled gently in an earthen pot for about 15 to 20 minutes. After cooling, natural honey (200ml) is blended with it. The optimum dosage of the syrup is $30 \mathrm{ml}$ twice a day (before breakfast and dinner) for a period of 90 days. Another promising drug for arteriosclerosis consists 
of fine gratings of ginger rhizome $(100 \mathrm{~g})$, cashew nut $(50 \mathrm{~g})$, black graphs $(50 \mathrm{~g})$ dates $(50 \mathrm{~g})$ jaggery $(100 \mathrm{~g})$ are mixed with required volume of natural honey $(500 \mathrm{ml})$, this potential ginger jam helps widening of narrowed blood vessels and heals gastrointestinal disorders in man (Dosage: 1 teaspoon twice a day) for a period of 3 months.

Table - 1 traditional therapeutic and agricultural uses of common plants in villages of Tirunelvli District, Tamil Nadu.

Sl. English Name Botanical Name Parts used Medicinal/ Agricultural use

1 Onion

2 Cashew nut

3 Garlic

4 Indian Aloes

$5 \quad$ Neem tree

$6 \quad$ Aprum

involucreatum

7 Lemon

$8 \quad$ Turmeric

$9 \quad$ Indian liquorice

10

Horse Radish

1

Touch - me - not

plant
Black cumin

13 Holy basil

14 Tomato

15 Betel leaf

16 Black pepper
Mimosa pudica

Allium cepa

Anacardium

occidentale

Allum sativum Bulb

Aloe vera

Leaf

Azadirachta indica Seed

Carum

roxburghianum

Citrus acida

Curcuma longa

Glycyrrhizae

glabra

Moringa

pterygosperma

Leaf

Leaf

Fruit

Rhizome

Root

Nigella sativa

Ocimum sanctum

Seed

Leaf

Physalis minima

Fruit

Piper betel

Leaf

Piper nigrum
Unripen

dried fruit
Antidote for poison of insects, centipedes etc.,

Arteriosclerosis

Arteriosclerosis, gastro intestinal disorders, fungicide, tonsillitis, hypertension, etc.

Skin cream, fungicide, etc.

Insecticide and plant growth promoter

Insect repellent

Skin ailments, Arteriosclerosis, gall bladder stones, diuretic, etc.

Snake repellent. Antiseptic etc.

Migrane

Giddiness due to gastro intestinal disorders and water

purifier

Eczema

Eczema

Fungicide

Skin cream and black patches

Tonsillitis

Tonsillitis, antidote for scorpion sting 


\begin{tabular}{|c|c|c|c|c|}
\hline 18 & Arjuna myrobalan & Terminalia arjuna & Leaf & Foot crack \\
\hline 19 & Graphs & Vitis vinifera & Fruit & Arteriosclerosis \\
\hline 20 & $\begin{array}{l}\text { Five }- \text { leaved } \\
\text { chaste tree }\end{array}$ & Vitex negundo & Leaf & $\begin{array}{l}\text { Insect repellent and plant } \\
\text { growth promoter }\end{array}$ \\
\hline 21 & Ginger & $\begin{array}{l}\text { Zingiber } \\
\text { officinalae }\end{array}$ & Rhizome & $\begin{array}{l}\text { Gastro intestinal disorders, } \\
\text { arteriosclerosis, insect repellent, } \\
\text { etc. }\end{array}$ \\
\hline \multicolumn{3}{|c|}{$\begin{array}{l}\text { Eczema } \\
\text { Oral administration of the leaf extract of the plant touch me not } \\
\text { ( } 25 \mathrm{ml} \text { l) twice a day for } 5 \text { days in an empty stomach of children } \\
\text { below the age } 5 \text { provides a comprehensive relief to Eczema. } \\
\text { External application of black cumin seed oil ( } 50 \mathrm{~g} \text { of black } \\
\text { cumin seed blended in } 100 \text { ml of coconut oil and boiled gently } \\
\text { over a flame for } 10 \text { minutes) over the blisters and ulcers of } \\
\text { eczema promotes rapid healing. }\end{array}$} & 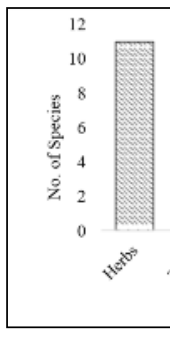 & 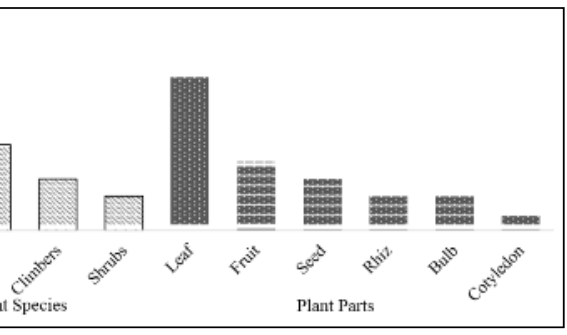 \\
\hline
\end{tabular}

Leaves of horse radish, rhizome of ginger and bulb of garlic (each $50 \mathrm{~g}$ ) are ground well in a mortar using required quantity of water. About $200 \mathrm{ml}$ of juice is extracted from the mixture which is then consumed along with a pinch of table salt (either sodium or potassium chloride) in an empty stomach in dawn on Sunday only. A single dosage serves as an alternate medication to get rid of giddiness owing to hyperacidity.

\section{Tonsillitis}

A semi solid paste capable of healing tonsillitis consists of 1 or 2 betel leaf, 4 or 5 seeds of black pepper, 2 or 3 bulb of garlic and honey ( 10 to $20 \mathrm{ml}$ ), it has to be roasted in an iron vessel until it solidifies. This chocolate like drug is orally administered once a day before to asleep in night for 3 consecutive day.

\section{Migraine}

A powder form of herbal drug is formed of anise seed, sugar crystals (diamond shaped), and Indian liquor ice (each $35 \mathrm{~g}$ ) has been orally given to patients to have a complete recovery from migraine (Dosage: $5 \mathrm{~g}$ drug in 10 to $15 \mathrm{ml}$ of natural honey thrice a day for two days)

\section{Insect repellent and plant growth promoter}

An alternative comprehensive ecofriendly botanical pesticide is prepared more economically by grinding the rhizome of ginger, the bulb of garlic and the leaf of five leaved chaste tree (each $100 \mathrm{~g}$ ) in a mortar in order to obtain a paste which is then blended with completely broken neem seeds $(1 \mathrm{~kg})$. This mother base is diluted liberally in 201 of water taken in a trough. To get an ideal matured insecticide, it is stirred for 5 minutes twice a day for a week. This bio pesticide is filtered using a tea filter, the recommended dosage is 30 to $40 \mathrm{ml} / \mathrm{l}$ of water for the insect pests of cereals, pulses, vegetables, fruits, oil seeds and ornamental flower yielding plant species. The leaf extractof Aprum involucreatum is a broad spectrum insect repellent which is sprayed upon crops to drive away insect species in lieu of chemical pesticides.

\section{Fungicide}

To avoid fungal infestations in agricultural crops, an organic fungicide is scrupulously prepares from the leaf extracts of Indian aloes, holy basil and bulb of garlic (each $500 \mathrm{~g}$ ) blended with water. This extract is filtered in a cotton cloth mesh to obtain the mother tincture (Dosage: $30 \mathrm{ml} / 1$ lit of water)

Figure - 1. Therapeutic plant species and their parts used by healers in the study area.

\section{DISCUSSION}

The present study revealed that new usage of 21 plant species (Table -1 and Figure - 1) belonging to 18 genera in the study area. Many of the medicinal preparations are reported for the first time in accordance with the folklore healers. The local residents have been using herbal remedies to get rid of common human diseases that include arteriosclerosis, skin disorders, migraine, gastrointestinal disorders, insect sting, foot crack, tonsillitis etc., similarly some herbal remedies are reportedly used by farmers as insect repellents and fungicide for agricultural crops.

Only a few remedies consists of single herbs (e.g. Insect sting and foot crack) but more than two herbs are reported in several preparations. Most of the herbal medicines are mixed with either honey or milk or coconut oil to activate the biochemical ingredients of the plant species responsible for antimicrobial activities and also to reduce or neutralize the ill effect of a wide range of phytochemicals. The Kani tribes of Kottoor reserve forest, Kerala have been orally administeringboth Zingiber officinale and Allium sativum in 10:1 ratio for treating stomach ache (Arun et al., 2007).

Pastes prepared from Mimosa pudica and Piper betel are used for external application in the treatment of pain and wounds respectively by the Kattunayakas tribes of Nilgiris District, Tamil Nadu (Udayan et al., 2007). The seeds of Pimpinella anisum, the root of Glycyrrhiza glabra and sugar crystals of Saccharum officinarum are ground well and this herbal medicine is used in the treatment of migraine in siddha (Murugesa Mudhaliyar, 1936). There are plenty of plant species available for pest control activities (pesticidal activities) that include vites, neem tree, Holy Basil, Black pepper, etc., remain unused or under used (Subramanian, 1999). Neam bears many bitter compounds like azadirachin, nimbin, salannin etc., of which azadirachtin acts as an antifeedant on the pests (Saxena et al., 1980 and Singh et al., 1990).

It is therefore absolutely imperative to document the precious indigenous knowledge on herbal medicine and botanical pesticides from the menace of over exploitation, bio piracy and habitat destruction (Singh et al., 1994 and Utkarsh et al., 1999). Further using new ideas on the home made herbal remedies, scientist may rely solely on making 
environmentally safe insecticides and plant based medicines to save humans from the potential hazards of existing of systems of exotic medication and pest control.

\section{REFERENCES}

1. Arun, V., Liju, V.B., Reena, J.V., Parthipan, B and Renuka, C., Traditional Remedies of Kani.

2. Tribes of Kottoor Reserve Forest, Indian Journal of Traditional Knowledge, 2007,6(4):589-594.

3. Augusti, K.T, Indian Medicinal Plants - Ficus bengalensis L, Salacia oblonga and Alliums as Possible Sources of Antidiabetic, Antioxidant and Hypolipidemic Principles. Medicinal Plants, Traditional Knowledge, I.K. International Publishing House Pvt.Ltd.,New Delhi, 2006,pp-61.

4. Dobriyal R.M and Narayana D.B.A, Ayurvedic Herbal Raw Material. The Eastern Pharmacist, April-1998,31 - 35.

5. Murugesa Mudhaliyar, C.S, Diddha Materia Medica, I Edition, Government Press Madrass, 1936, pp 11,575.

6. Narayanasamy, P.,TraditionalWisdom of Plants in Pest Control in Agriculture. I.K. International

7. Publishing House Pvt.Ltd. New Delhi, 2006, pp. 160

8. Pradhan, S., Jotwani, M.G., and Raj, K., The Neem Seed Deterrent to Locust, Indian Farming,

9. 1962,22(8):7-11.

10. Saleem Ahmed and Gaby Stoll., Bio pesticides, 1996, pp 52-79.

11. Sane, R.T., Standardisation, Qulity Control and GMP's for Herbal Drugs. Indian Drugs, 2002

12. 39(3): 184 .

13. Saxena, R.C., Liquido, N.J. and Justo, H.P., Neem Seed Oil a Potential Antifeedent for the control of the Rice brawn Planthopper Nilaparvata lugens, Proc.Int.Neem Conf.Rotach.Egem, 1980,pp

14. $171-188$.

15. Singh, J., Sukhija, H.S. and Pramjit, S., Evaluation of Neem Oil Against Neem LeafFolder and

16. Stem Borer, Proc. Symp., on Botanical Insecticides in IPM, Rajamundry, 1990 pp 288-290.

17. Singh, J.S., Raghubanshi, A.S., and Varshney, C.K., Integrated Biodiversity Research in India, Current Science, 1994,66(2): 109

18. Subramaniam, B., Under exploited Insecticidal Plants of Potential Agricultural Use pp 71- 83, Bio pesticides in Insect Management, Phoenix Publishing House Pvt.Ltd.,New Delhi, 1999, p. 262.

19. Udayan, P.S., Tushar, K .V., Satheesh, Gand Indira, B., Ethinomedicinal Information from

20. Kattunayakas Tribes of Mudumalai Wild life Sanctury, Indian Journal of Traditional Knowledge,

21. 2007,6(4):574-578.

22. Urkarsh, G.M., Gadgil, M., and Rao, P.R.S., Intellectual Properties Rights on Biological

23. Resources: Benefiting from Biodiversity and People's Knowledge, Current Science, 1999, 77(11):

24. 14,18

25. Venkata Rao,E., Scope of Plant Drugs in Modern Medicine.Visakha Science J., I, 1997, 47 . 